\title{
Analisis Lagu Mudiak Arau Dalam Pertunjukan Talempong Pacik Ikua Parik Kanagarian Limbanang
}

\author{
Try Wahyu Purnomo ${ }^{1}$, Sri Mustika Aulia ${ }^{2}$ \\ Prodi Pendidikan Guru Sekolah Dasar, Fakultas Ilmu Pendidikan, \\ Universitas Negeri Medan, Jl Willem Iskandar Pasar V Medan Estate, \\ Sumatera Utara, Indonesia \\ Email: twahyu@unimed.ac.id
}

\begin{abstract}
Abstrak
Penelitian ini bertujuan untuk memaparkan hasil penelitian mengenai analisis teks dan konteks dari lagu Mudiak Arau Dalam Pertujukan Talempong Pacik Ikua Parik Kanagarian Limbanang. Penelitian ini menggunakan pendekatan kualitatif dengan metode content analysis (analisis konten) yang bersifat desskriptif. Analisis secara tekstual dilakukan dengan membahas penggunaan ritme, melodi, serta sistem penulisan notasi lagu Mudiak Arau yang disajikan dalam pertunjukan Talempong Pacik Ikua Parik. Selanjutnya analisis kontekstual dilakukan dengan cara mendeskripsikan struktur pertunjukan, filosofi alam sebagai landasan musikal, dan juga teknik memainkan teknik yang digunakan dalam memainkan lagu tersebut pada pertunjukan Talempong Pacik Ikua Parik. Berdasarkan hasil analisis tersebut maka dapat dilihat secara khusus mengenai ciri khas dan karakteristik pada lagu Mudiak Arau yang dimainkan pada pertunjukan Talempong Pacik Ikua Parik di Kanagarian Limbanang.

Kata Kunci: Talempong Pacik, Lagu Mudiak Arau, Tradisional Minangkabau
\end{abstract}

\begin{abstract}
This study aims to present the results of research on the analysis of the text and context of the song Mudiak Arau in Talempong Pacik Ikua Parik Kanagarian Limbanang Performance. This study uses a qualitative approach with a descriptive content analysis method. Textual analysis was carried out by discussing the use of rhythm, melody, and the system of writing Mudiak Arau's song notation which was presented in the Talempong Pacik Ikua Parik performance. Furthermore, contextual analysis is carried out by describing the structure of the performance, natural philosophy as a musical foundation, and also the technique of playing the techniques used in playing the song in the Talempong Pacik Ikua Parik show. Based on the results of this analysis, it can be seen specifically about the characteristics and characteristics of the Mudiak Arau song played at the Talempong Pacik Ikua Parik show in Kanagarian Limbanang

Keywords: Talempong Pacik, Mudiak Arau Song, Traditional Minangkabau.
\end{abstract}




\section{PENDAHULUAN}

Minangkabau merupakan salah satu etnis di indonesia yang berada di wilayah Sumatera Barat. Pada dahulunya wilayah Minangkabau di bagi menjadi tiga yaitu wilayah Darek, Rantau dan Pasisia. Setiap wilayah mempunyai daerah dan batasannya masing-masing. Wilayah Darek menurut sejarahnya merupakan wilayah asli Minangkabau, adapun daerahnya terdiri dari Luhak nan Tigo yaitu Luhak Agam, Luhak Tanah Data, Luhak 50 koto. Wilayah rantau Minangkabau adalah daerah di luar Luhak Nan Tigo yang awalnya merupakan tempat mencari kehidupan bagi orang Minangkabau. Selain itu juga ada daerah Ujuang Darek Kapalo Rantau, yakni daerah perbatasan wilayah luhak dan rantau. Masing-masing luhak memiliki wilayah rantau sendiri. Wilayah pasisia adalah daerah sepanjang pantai barat Pulau Sumatra bagian tengah, membentang dari perbatasan Minangkabau dengan Tapanuli selatan hingga Muko-Muko (Bengkulu). Masingmasing daerah di Minangkabau memiliki bermacam-macam kesenian yang menjadi ciri khas daerah tersebut. Seabagai contoh misalnya kesenian Talempong Pacik yang terdapat di daerah Solok (Luhak Tanah Data) dengan kesenian Talempong Pacik yang terdapat di daerah Payakumbuh (Luhak 50 koto) tentu akan berbeda. Perbedaan tersebut meliputi, struktur pertunjukan (Macam-macam alat yang digunakan) atau pun materi dari Talempong Pacik nya sendiri. Perbedaan ini dikarenakan beberapa faktor yaitu pengaruh lingkungan, sejarah, maupun peran dari seniman nya sendiri. Di dalam kehidupannya masyarakat Minangkabau memegang suatu landasan falsafah "Alam Takambang Jadi Guru" yang menjadi pedoman bagi setiap masyarakat. Alam tidak hanya dipandang sebagai tempat berlangsungnya suatu kehidupan, akan tetapi alam menjadi sumber belajar baik itu sebagai pedoman dalam mejalani kehidupan maupun dalam merumuskan hal-hal yang menyangkut tentang adat-istiadat Minangkabau itu sendiri. Kesenian sebagai hasil dari karya masayarakat juga tidak terlepas dari landasan filosofis tersebut, sebagai contoh nya pemaknaan terhadap alam sering dituangkan kedalam petatah-petitih adat. Dalam pembentuk kan suuatu kesenian (Talempong Pacik) masyarakat Minangkabau juga selalu mengacu kepada alam sebagai sumber belajarnya.

Pada umunya masyarakat Minangkabau sudah mengetahui bahwa salah satu cara memainkan alat musik Talempong adalah dengan car dipegang (Dipacik). Istilah Talempong Pacik diberikan oleh para seniman tradisional akademisi untuk membedakan klasifikasi Talempong berdasarkan tekhnik permainannya. Sekitar Tahun 1965-1970 para staf pengajar di ASKI Padang Panjang (Berubah menjadi STSI tahun 1997 dan kembali berubah menjadi ISI pada tahun 2010) yang terdiri dari Irsyad Adam, Akhyar Adam, Murad St. Saidi, dan Datuak Jolabiah, dibantu dengan Bustanul Arifin (Ketuan ASKI Padang Panjang pada masa itu) menetapkan pemakaian istilah Talempong Pacik dengan tujuan memperjelas konsep genre musik talempong di Minangkabau yang beraneka ragam (Hanefi dkk, 2004 p.9). Adapun tujuan dari dipopulerkan istilah Talempong Pacik yaitu (1) Istilah Talempong Pacik memberi pemahaman yang lebih jelas terhadap pengkajian dan penelitian aneka ragam musik Talempong yang ada di Minangkabau. Akibatnya dapat melahirkan informasi ilmiah yang berangkat dari klasifikasinya yang khas, sesuai konsep musikal dan genre musik Talempong itu, termasuk cara permainannya, (2) Istilah Talempong Pacik dapat lebih mempertegas pengertian konsep musikal terhadap dua tekhnik permainan genre musik Talempong yang hidup di Alam Minangkabau, yaitu genre musik Talempong yang menggunakan tekhnik interlocking (Talempong Pacik) dengan jenis Talempong yang dimainkan dengan cara melodis (Talempong Duduak).

Setiap Nagari (desa) di Minangkabau memiliki kesenian Talempong Pacik yang beragam, dan biasanya dinamakn sesuai dengan tempat asalnya Talempong Pacik tersebut seperti Talempong Ikua Parik di daerah di daerah Ikua Parik, Luhak 50 Koto dan Talempong Ateh Guguak di daerah . Pada bentuk pertunjukan Talempong Pacik biasa dimainkan dengan 4 sampai 8 orang pemain. Pada pertunjukan umumnya, Talempong Pacik dimainkan dengan 4 orang yaitu 1 orang memainkan gendang dan 3 orang memainkan Talempong. Para player memainkan talempong 
dengan fungsi yang berbeda, yaitu memainkan Talempong Jantan, Talempong batino dan Talempong panyaua.

Talempong Pacik Ikua Parik merupakan kesenian Talempong yang berasal dari daerah Ikua Parik, nagari Limbanang, Kecamatan Suliki , Kabupaten Lima Puluh Kota. Nagari Limbanang memiliki luas $15,48 \mathrm{~km}^{2}$, yang menjadi wilayah terkecil diantara nagari-nagari lain dalam Kecamatan Suliki. Nagari Limbanang terdiri dari empat jorong yaitu Penago, Ikua Parik, Limbanang Baruah dan Saut (Fulzy, 2011). Topografi nagari Limbanang bergelombang yang terdiri dari daerah dataran dan bukit-bukit kecil. Limbanang di aliri oleh sungai (batang) Sinamar sebagai sungai terpanjang yang mengaliri hampir seluruh Kecamatan Suliki dan berhulu ke daerah perbukitan yang disebut bukit Gadang. Masayarakat Limbanag umunya berbicara dengan dinamika suara sedang dan intonasi suara yang mengalun. Merupakan pengaruh ekologi dari topografi tanahnya yang cenderung datar, memiliki banyak anak sungai, dan kecendrungan masyarakatnya tinggal di sepanjang aliran sungai. Kesenian Talempong Pacik Ikua Parik merupakan suatu kesenian yang menjadi identitas bagi masyarakat di jorong Ikua Paruik kanagarian Limbanang

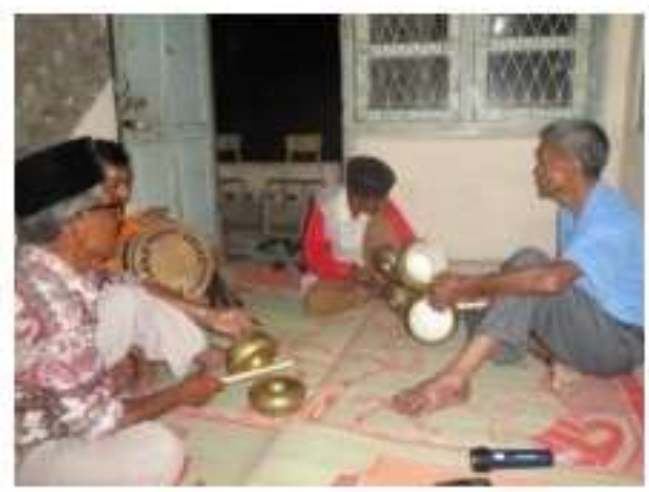

Gambar 1. Penyajian Talempong Pacik Ikua Parik Kanagarian Limbanang Sumber: (Fulzy, 2011)

\section{METODE PENELITIAN}

Penelitian ini merupakan penelitaian kualitatif yang bersifat deskrptif. Bogdan dan Taylor (dalam Moleong, 2005, hlm. 4) menyatakan bahwa penelitian kualitatif merupakan penelitian yang menghasilkan data deskriptif berupa kata-kata tertulis atau lisan dari orang-orang dan perilaku yang diamati. Selanjutnyta pendekatan penelitan yang digunakan adalah analisis isi (content analyisis). Dalam menganalisis sebuah objek harus memenuhi tiga aspek, yaitu: (1) Objektivitas, penggunaan simbol-simbol musikal dalam sebuah transkripsi, (2) Sistematis, analisis yang dibedah secara terstruktur, (3) Generatif, data hasil analisis dapat memberikan sumbangan dalam bentuk teoretik (Kuswara, Yensharti, \& Toruan, 2013)

Lagu yang dijadikan objek analisis adalah Lagu Mudiak Arau yang dimainkan dalam pertunjukan Talempong Pacik Ikua Parik di Kanagarian Limbanang. Adapun teknik analisis data yang dilakukan adalah (1) mengidentifikasi lagu Mudiak Arau, (2) mengklasifikasikan unsur teks dan konteks yang akan dianalisis, (3) mendeskripsikan hasil analisis yang meliputi aspek tekstual (penggunaan ritme, melodi, serta sistem penulisan notasi lagu) dan aspek kontekstual (mendeskripsikan struktur pertunjukan, filosofi alam sebagai landasan musikal, dan juga teknik permainanyang digunakan dalam memainkan lagu tersebut), (4) Verifikasi atau memaparkan hasil analisis untuk melihat ciri khas dan karakteristik dari lagu Mudiak Arau (Purnomo, 2017). 
Dalam bentuk analisis lagu yang dimainkan pada pertunjukan Talempong Pacik Ikua Parik dilakukan dengan pendekatan Konteks dan Teks. Hal ini sesuai dengan pendapat. Pande Made Sukerta (2011) menjelaskan bahwa pada kesenian tradisional khususnya karya musik dapat dilihat dari teks dan konteks. Teks dengan musikal yang mengandung unsur-unsur: instrument, organologi, repertoar, pelarasan, garap dan pemain, jadi bisa diartikan teks merupakan wujud dari kesenian itu sendiri. Konteks mempunyai dua pengertian yaitu, sebuak karya musik sebagai konteks karya dan masyarakat yang terkait dengan kondisi, situasi termasuk keprluannya adalah konteks sosial (kultural) diantaranya meliputi: lokasi, potensi kesenian, penyebaran, dan latar belakang. (Sukerta, 2011)

\section{HASIL DAN PEMBAHASAN Analisis Konteks \\ Struktur Pertunjukan Talempong Pacik Ikua Parik}

Secara struktur pertunjukan Talempong Pacik Ikua Parik apabila dilihat dari segi penggunaan instrument, dalam pertunjukan ini menggunakan enam buah Talempong dan satu Gandang. Para pemain kesenian Talempong Pacik Ikua Parik terdiri dari 3 orang pemain Talempong (masing-masingnya memainkan 2 buah Talempong) dan satu orang memainkan Gandang.

Peamain pertama memegang Talempong bernada 2-4 disebut dengan istilah Polong , pemain kedua memegang Talempong yang bernada 1-3 disebut dengan istilah Tongah, pemain ketiga memegang Talempong yang bernada 5-6 disebut dengan istilah Tingkah, dan pemain Gandang disebut dengan Tukang Gandang. Kunci permainan Talempong Pacik Ikua Parik terletak pada jalinan nada Talempong yang satu dengan yang lainnya sehingga terbentuk suatu alunan melodis yang utuh.

\section{Alam Sebagai Sumber Karakter Musikal}

Masyarakat Minangkabau sendiri memegang teguh terhadap falsafah adat Minangkabau yaitu "Alam Takambang Jadi Guru” artinya alam merupakan sumber belajar bagi masyarakat Minang. Alam tidak hanya dijadikan sebagai tempat bermukim, tempat lahir dan tempat mati, tempat hidup dan berkembang akan tetapi juga mempunyai makna filsofis. Masyarakat Limbanang khusunya Jorong Ikua Paruik juga memiliki perumpamaan garitiak cando aia ilia bak kacimpuang mandi yang digunakan oleh seniman selaku pemain Talempong Pacik Ikua Parik (Fulzy, 2011). Istilah ini digunakan untuk menggambarkan tekhnis permain kesenian mereaka yang sebenarnya bersumber dari karakter alam Limbanang yang banyak di aliri oleh anak-anak sungai.

Anak-anak sungai di Limbanang sebagai cabang dari Batang Sinamar juga berhulu di daerah tersebut. Karakter aliran airnya cukup deras namun dengan suara riak yang tenang. Karakter bunyi aliran inilah yang di adopsi ke tekhnik permainan garitiak oleh seniman. Konsep bunyi garitiak yang baik dan indah adalah seperti riak air sungai mengalir deras akan tetapi dengan intensitas bunyi yang tidak keras. Pengaruh kestabilan aliran air Batang Sinamar yang oelh masyarakat Limbanang digambarkan dengan perumpamaan panuahnyo ndak sampai malimpah kariangyo ndak sampai babucak (penuhnya tidak sampai melimpah, keringnya tidak sampai ke dasar), tercermin pula dalam konsep ornamentasi (garitiak) Talempong tingkah. Artinya kestabialan ritme garitiak harus dalam porsi yang sewajarnya. Jika Ritme garitiak berlebihan maka akan menutupi (membanjiri) bangunan melodi lagu sehingga melodi tidak terdengar jelas, sebaliknya apabila terlau jarang, akan membuat melodi utama akan terkesan kering. (Fulzy, 2011) 


\section{Teknik Memainkan}

Talempong Pacik Ikua Parik merupakan suatu kesenian yang merupakan pengembangan dari kesenian Talempong Pacik sendiri. Pengembangannya terlihat pada perbedaan tekhnik permainan interlocking dan lagu-lagu yang dibawakan berasal dari lagu-lagu Dendang Saluang. Untuk hal tekhnik permaianan Talempong Pacik Ikua Parik sedikit berbeda dengan cara memainkan Talempong Pacik pada umunya. Talempong Pacik pada umumnya menggunakan sistem interlocking dalam permainannya, akan tetapi dalam kesenian Talempong Pacik Ikua Parik apabila di analogikan ke dalam pendekatan musik barat maka akan cendrung bersifat hoecketing (bersilang) dalam hal permainannya (Nadia). Hoecketing menurut Willi (dikutip dalam Fulzy, 2016) merupakan suatu perselang-selingan dari dua (terkadang tiga) suara dengan tunggal atau sekelompok nada pendek. Pada Talempong Pacik Ikua Parik para pemain harus memukul susunan pasangan nada bersilang tersebut secara ber gantian deni menghindari pembenturan nada-nada. Akhirnya akan dibentuk melodi lagu yang utuh. Tekhnink basilang (hoecketing) khas Talempong Pacik Ikua Parik ini tidak ditemukan pada ensambel-ensambel Talempong tradisional lain di Minangkabau. Materi dan tekhnik permainan Talempong Pacik Ikua Parik yang spesifik menyebabkan kesenian ini memiliki karakter musikal yang berbeda dari ensambel lainnya di Minangkabau.

\section{Analisis Teks}

\section{Lagu Mudiak Arau}

Seperti yang telah dijelaskan pada bagian sebelumnya bahwa, pada struktur pertunjukan Talempong Pacik Ikua Parik, melodi yang dibawakan oleh Talempong tersebut merupakan repertoar yang bersal dari dendang Saluang Darek. Salah satu lagu dari Saluang Darek yang sering dibawakan oleh Talempong Pacik Ikua Parik ialah lagu Mudiak Arau. Lagu Mudiak Arau merupakan lagu yang cukup populer di kalangan Masyarakat Minangkabau. Lagu Mudiak Arau pada dasarnya berupa melodi vokal atau melodi Saluang Darek yeng bersifat Melismatis. Kekuatan ritmis dari lagu tersebut muncul dari permainan alat musik nya. Untuk analisis teks kali ini penulis akan memfokuskan pembahasan kepada perbedaan ritme yang dihasilkan oleh Talempong yang dimainkan oleh ketiga pemain, Polong, Tongah dan Tingkah sehingga membentuk suatu struktur lagu dendang Saluang Darek.

\section{Sistem Penulisan Notasi}

Sistem notasi yang di gunakan berdasarkan pendekatan dari teori musik barat hanya mencerminkan sebagian besar dari esensi musikal yang sebenarnya. Dengan demikian, semua notasi tinggi rendah hanya merupakan suatu bentuk pendekatan untuk menganalisis teks dari Talempong Pacik Ikua Parik secara musikalitasnya, maka penulis menggunakan istilah (Talempong 1 - Talempong 6). Nada Talempong pada hakekatnya tidak sama persis dengn nadanada di musik barat yang digunkana dalam sisitem notasi.

\section{Analisis Ritme}

Ritme merupakan suatu bunyi dalam waktu. Menurut Muttaqin (Muttaqin, 2008). Ritme adalah susuanan diantara durasi nada-nada yang pendek dan panjang, nada-nada yang bertekanan dan yang tak bertekanan menurut pola tertentu. Dalam suatu bentuk lagu pengelompokan ritme (tanda birama) terdapat dalam garis paranada setelah kunci (clef). Dalam kebutuhan musik untuk penulisan notasi, ritme digambarkan dalam bentuk simbol tertentu (not balok). 
Tabel 1. Bentuk, Nama dan Kualitas Not

\begin{tabular}{|c|c|c|c|}
\hline \multirow{2}{*}{ Bentuk Nada } & \multicolumn{2}{|c|}{ Nama Nada } & \multirow{2}{*}{ Tanda Istirahat } \\
\cline { 2 - 3 } & Angka & Kualitas & \\
\hline \multirow{2}{*}{ Penuh/ whole } & Semi Brave & \\
\hline & $1 / 2$ & Minim & \\
\hline & $1 / 8$ & Crotchet & \\
\hline & $1 / 16$ & Quaver & 7 \\
\hline & $1 / 32$ & Semi Quaver & $\%$ \\
\hline
\end{tabular}

Dalam keseluruhan ritme yang dihasilkan oleh instrument di kesenian Talempong Pacik Ikua Parik hanya menggunakan beberapa not saja yaitu not $1 / 4$ ( - ) dengan kualitas crotchet, not $1 / 8\left({ }^{-}\right)$dengan kualitas quaver dan not $1 / 16\left({ }^{\circ}\right)$ dengan kualitas semi quaver. Hal ini dikarenakan, secara keseluruhan walaupun dalam struktur lagu beberapa instrument membentuk pola melodi akan tetapi secara hakikat instrument Talempong merupakan alat perkusi sehingga ritme yang dihasilkan untuk membentuk melodi tersebut akan cendrung lebih pendek.

Untuk aspek nada, analisis dilakukan dengan menggunakan sistem nada dengan pendekatan terhadap bentuk penalaan di musik barat. Akan taetapi setiap nada tentunya tidak memiliki penalaan nada yang tepat sesuai dengan konsep musik barat, oleh karena itu penulis hanya memberi simbol seperti (T1 - T6) untuk kebutuhan penulisan notasinya. Adapun pendekatan terhadap scale yang terdapat pada semua Talempong dapat dituliskan di dalam pertitur

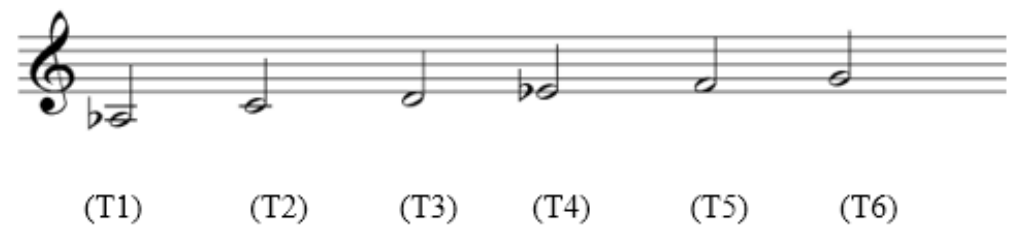

Gambar 2. Sistem Penulisan Notasi dengan Simbol yang Berbeda

Masing-masing Talempong memproduksi pola ritme yang saling berkaitan antara satu dengan yang lainnya sehinggam membentuk suatu kesatauan melodi yang utuh. Masing-masing pemain memainkan dua buah Talempong (dengan nada yang tetap).

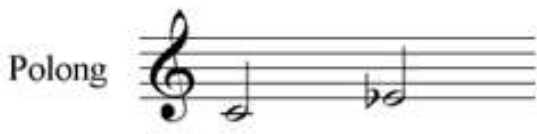

(T2)

Gambar 3. Pemain Polong memainkan Talempong 2 dan 4 
Tongah

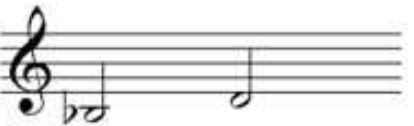

(T1)

Gambar 4. Pemain Tongah memainkan Talempong 1 dan 3

Pemain Paningkah memainkan Talempong 5 dan 6. Prinsip permain Paningkah adalah mengiri perjalanan melodi utama lagu, dan sesekali juga ikut membangun melodi jika diperlukan.

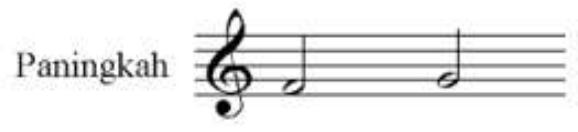

(T5) (T6)

Gambar 5. Paningkah meamainkan Talempong 5 dan 6

Pada bagian pertama dari pertunjukan Talempong Pacik Ikua Parik akan diberkian pengantar beberapa pola rime yang dihasilkan oleh instrument Talempong dan Gandang. Pengantar tersebut berperan sebagai Intro dalam suatu struktur lagu. Dalam bagian pertama ini, isntrument Talempong dan Gandang tidak membentuk suatu melodi sebagaimana yang dilakukan pada bagian inti dari pertunjukan Talempong Pacik Ikua Parik. Bagian pengantar ini hanya memainkan beberapa pola ritme dengan sistem interlocking (sebagaimana lazim nya tekhnik memainkan Talempong Pacik). Adapun bentuk keseluruhan dari penulisan notasi untuk bagian pengantar di kesenian Talempong Pacik Ikua Parik dapat di lihat sebagai berikut 

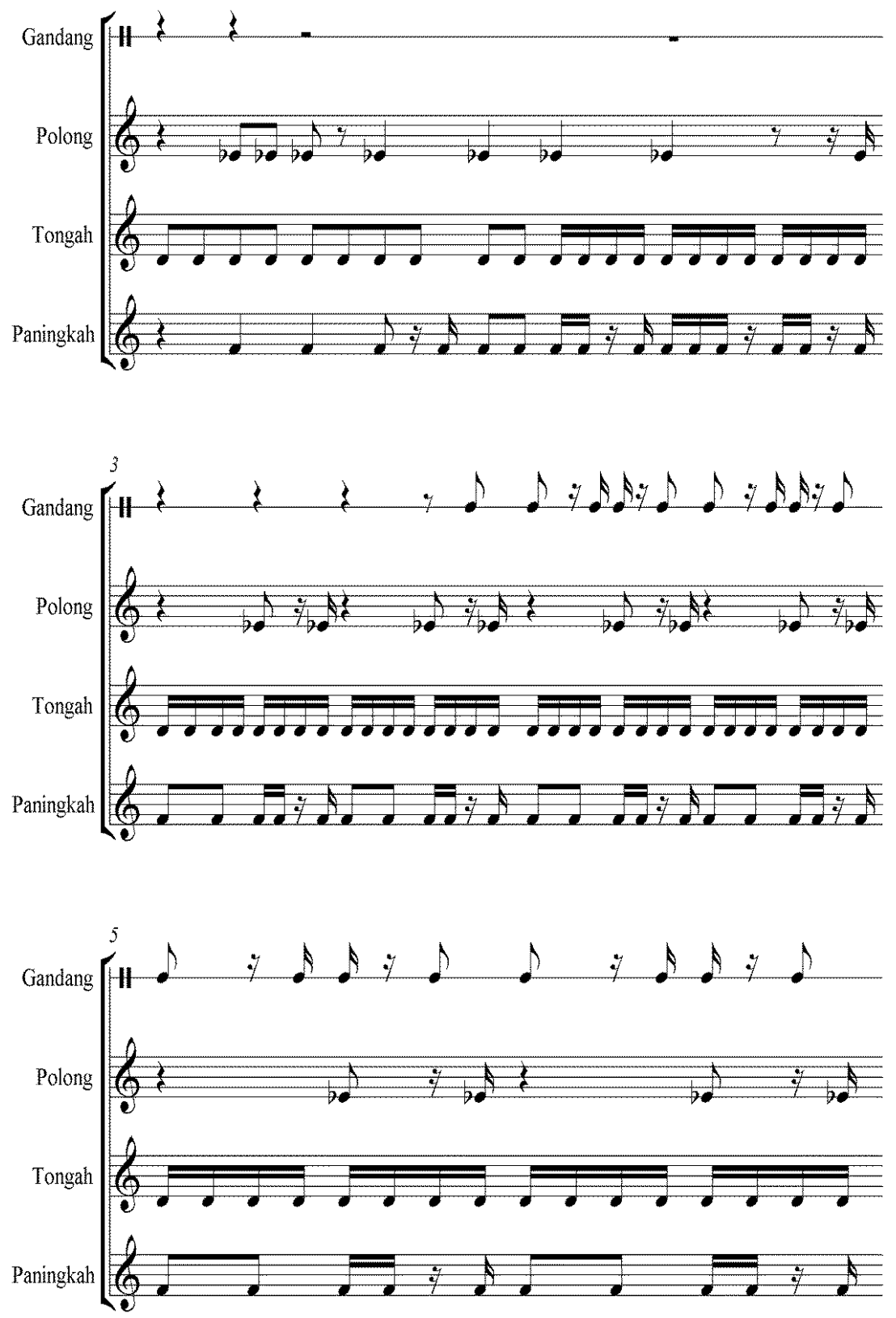

Gambar 6. Bagian Pengantar

Bagian awal, pemain Tongah (T1 - T3) memulai dengan memperoduksi not 1/8 (quaver) di kuti dengan pemain Paningkah (T5 - T6) yang memainkan not 1/4 (crotchet) dengan aksen pada ketukan beat. Pemain Polong (T2 - T4) pada bagian pengantar ini cendrung menghasilkan ritme yang berfungsi sebagai ornamentasi dengan menggunakan 1/16 (semi quaver). Pola ritme gendang pada struktur lagu secara keseluruhan cenderung sama. Artinya instrument Gendang menghasilkan rime yang berfungsi sebagai pola iringan pada struktur lagu.

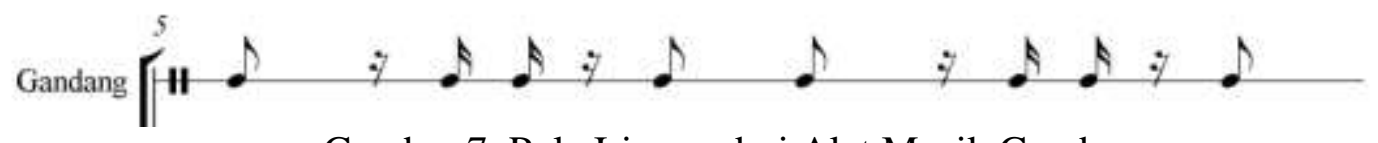

Gambar 7. Pola Iringan dari Alat Musik Gandang 
Grenek: Jurnal Seni Musik Vol. 10 No. 1 (Juni 2021) Page: 46-59

Prodi Pendidikan Musik FBS Unimed

p- ISSN 2301-5349

e- ISSN 2579-8200

Secara keseluruhan ritme yang dihasilkan oleh masing-masing Talempong di bagian pengantar ini dimainkan secar Interlocking (saling mengisi). Selanjutnya masuk kepada struktur lagu inti yang membentuk pola melodi dari lagu "Mudiak Arau". Adapun transkripsi secara keseluruhan dari bagian inti dapat dilihat sebagai berikut.

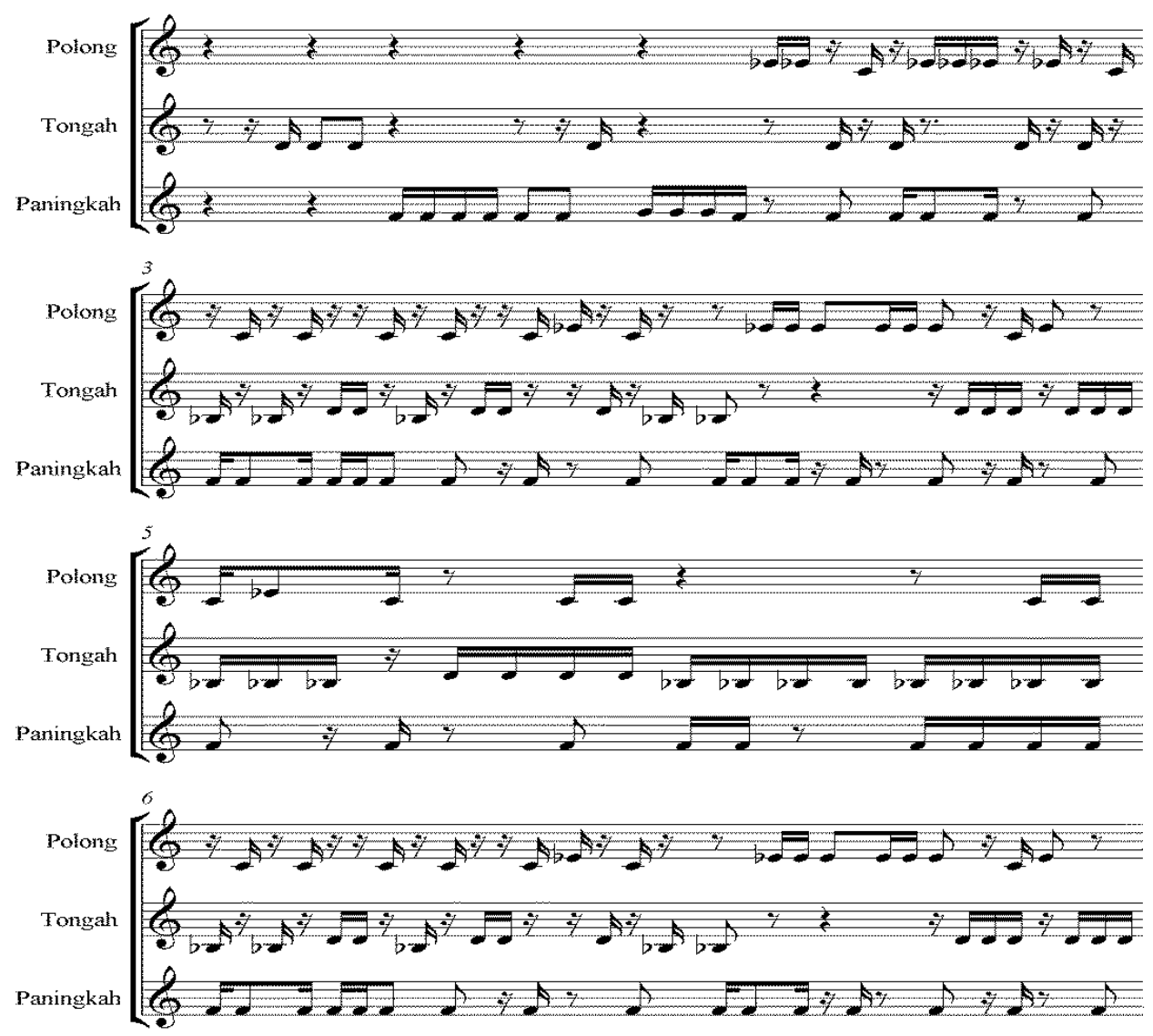

2

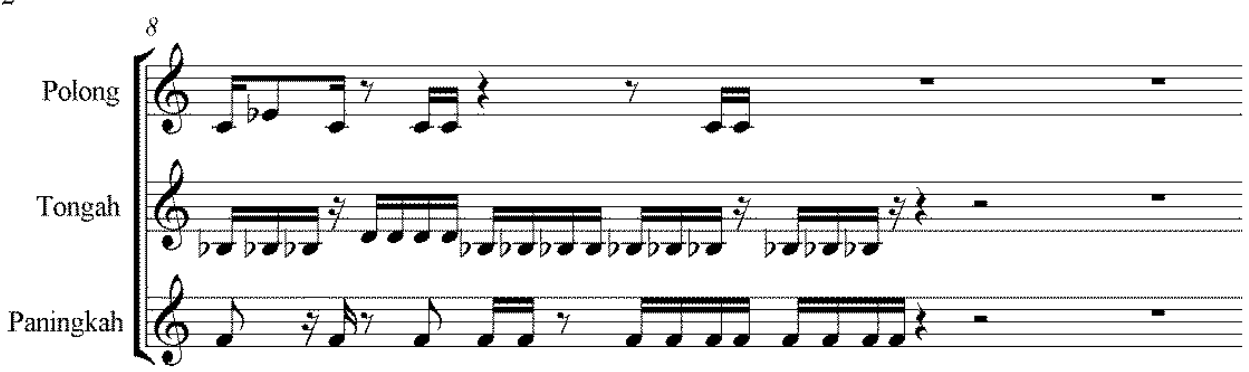

Gambar 8. Bagian Inti dari Lagu

Bagian inti dari lagu di mulai dengan rime yang dihasilkan oleh pemain Tongah . Ritme yang dihasilkannya terdengar seperti kode yang menandakan untuk memainkan ke bagian berikutnya. 


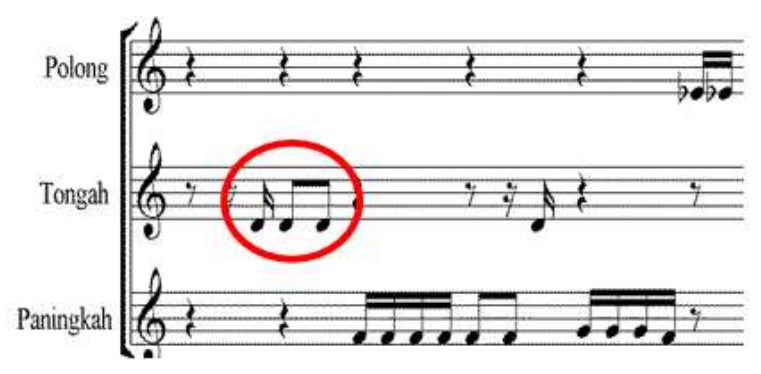

Gambar 9. Kode dari Talempong Tongah

Talempong Tongah dan Talempong Polong membentuk melodi dengan menggunakan tekhnik hoecketing (bersilang). Talempong Paningakah juga turut membangun melodi pada nadanada tertentu , tetapi sering juga dimainkan secara bersamaan dengan nada-nada lainnya. Hal ini terlihat dari bagian awal pada struktur melodi inti, setiap pengulangan melodi oleh nada-nada Paningkah (T5-T6) menjadi bagian yang penting sebagai bagian dari lagu.

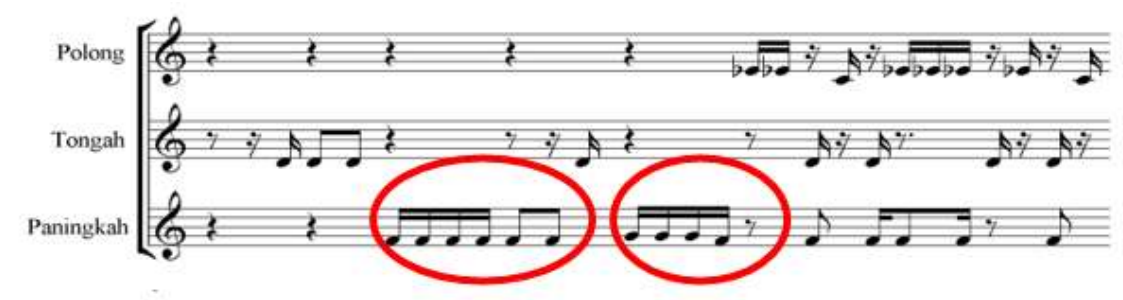

Gambar 10. Ritme Paningkah Sebagai Pembentuk Melodi

Sebagaimana dalam tekhnik hoecketing (bersilang), proses pembentukan melodi jarang mengalami pembenturan nada. Pengecualian pada Talempong Tingkah yang justru secara sengaja menghadirkan pembenturan nada secara intens berupa motif-motif Tingkah ostinato yang lazim disebut garitiak. Ostinato difungsikan terhadap melodi dan harus memiliki ritme yang kontras dengan melodi aslinya, apabila ostinato sesuai dengan pola harmonik dari lagu, maka akan diteruskan sebagai bagian pengiring untuk melodi (Budhidharma, 2001). Hal ini dapat dilihat dari munculnya nada Garitiak yang dihasilkan oleh Talempong Paningkah (T5-T6) yang di aplikasikan ke dalam melodi utama yang dibentuk secara dominan oleh Talempong Polong (T2-T4) dan Talempong Tongah (T1-T3). Apabila penulisan pola ritme dari Talempong Polong (T2-T4) dan Talempong Tongah (T1-T3) digabungkan sebagi melodi utama maka akan dapat terlihat bahwa ritme yang dihasilkan oleh Talempong Paningkah akan membentuk ostinato 


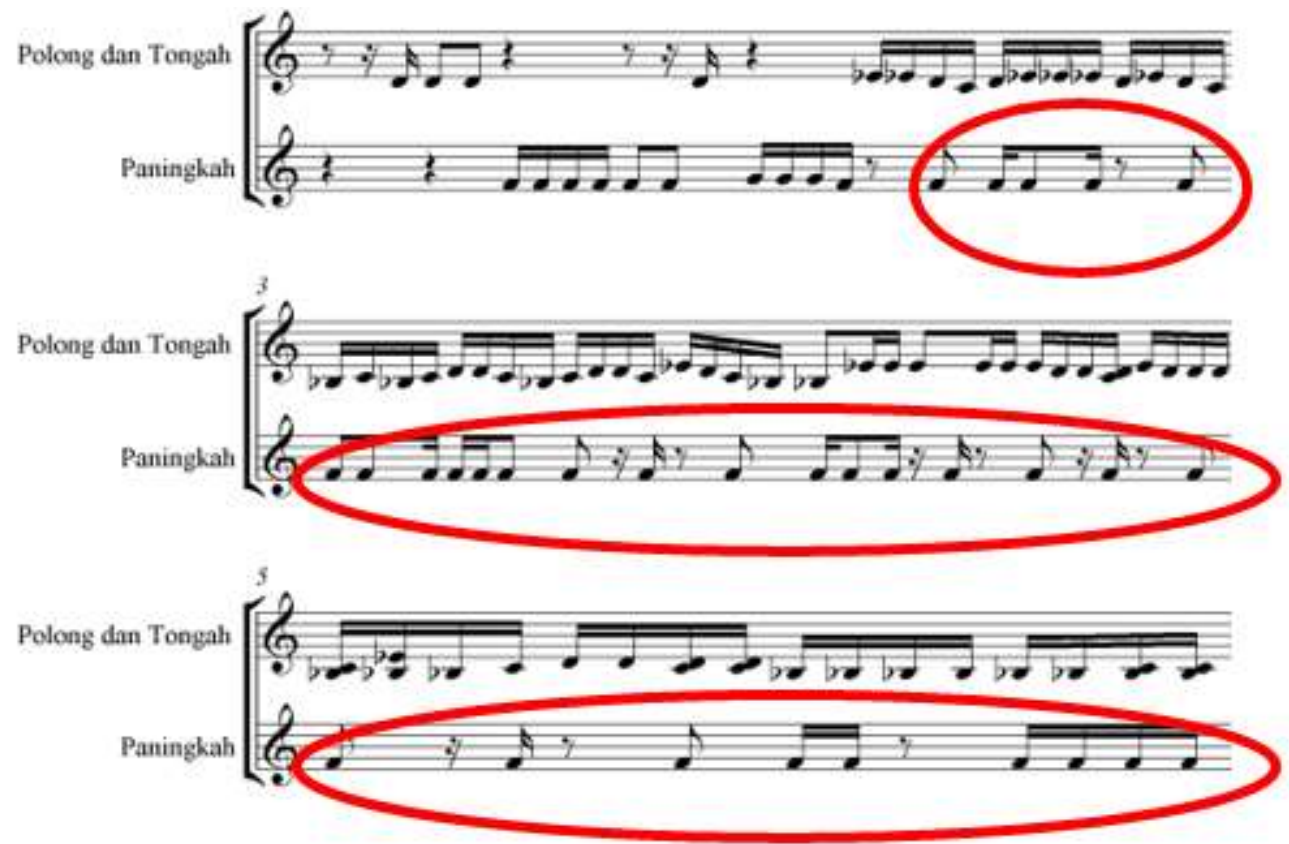

Gambar 11. Pola Ostinato dari Talempong Paningkah

Nada garitiak bersifat spontan, sehingga dapat dianalogikan sebagai ornamentasi dalam ilmu musik barat. Menurut Apel (Dikutip dalam Fulzy, 2006) ornamentasi berasal dari aksi spontan pemain yang menanmbahi, mengembangkan atau memvariasikan melodi asli melalui tekhnik improvisasi sendiri. Berdasarkan pengamatan terhadap transkripsi dari kesenian Talempong Pacik Ikua Parik penggunaan not-not 1/16 terlihat sangat signifikan dibandingkan not-not yang memilki kualitas lebih besar, baik pada bangunan melodi yang dibentuk oleh Talempong Polong dan Tongah maupun pada unit Paningkah . Not $-1 / 16$ secara audio memiliki durasi bunyi yang sangat pendek, sehingga melodi dan tingkah yang dibangun oleh dominasi not - 1/16 akan memiliki tingkat kerapatan ritmik yang tinggi. Dari keseluruhan dari bagian lagu "Mudiak Arau" yang di mainkan di kesenian Talempong Pacik Ikua Parik, dapat dilihat bahwa terdapat beberapa varian not yang di produksi oleh semua instrument, diantaranya, not • 1/4 dengan kualitas crotchet, not $-1 / 8$ dengan kualitas quaver dan not $1 / 16$ dengan kualitas semi quaver. 
Grenek: Jurnal Seni Musik Vol. 10 No. 1 (Juni 2021) Page: 46-59

Prodi Pendidikan Musik FBS Unimed

p- ISSN 2301-5349

e- ISSN 2579-8200

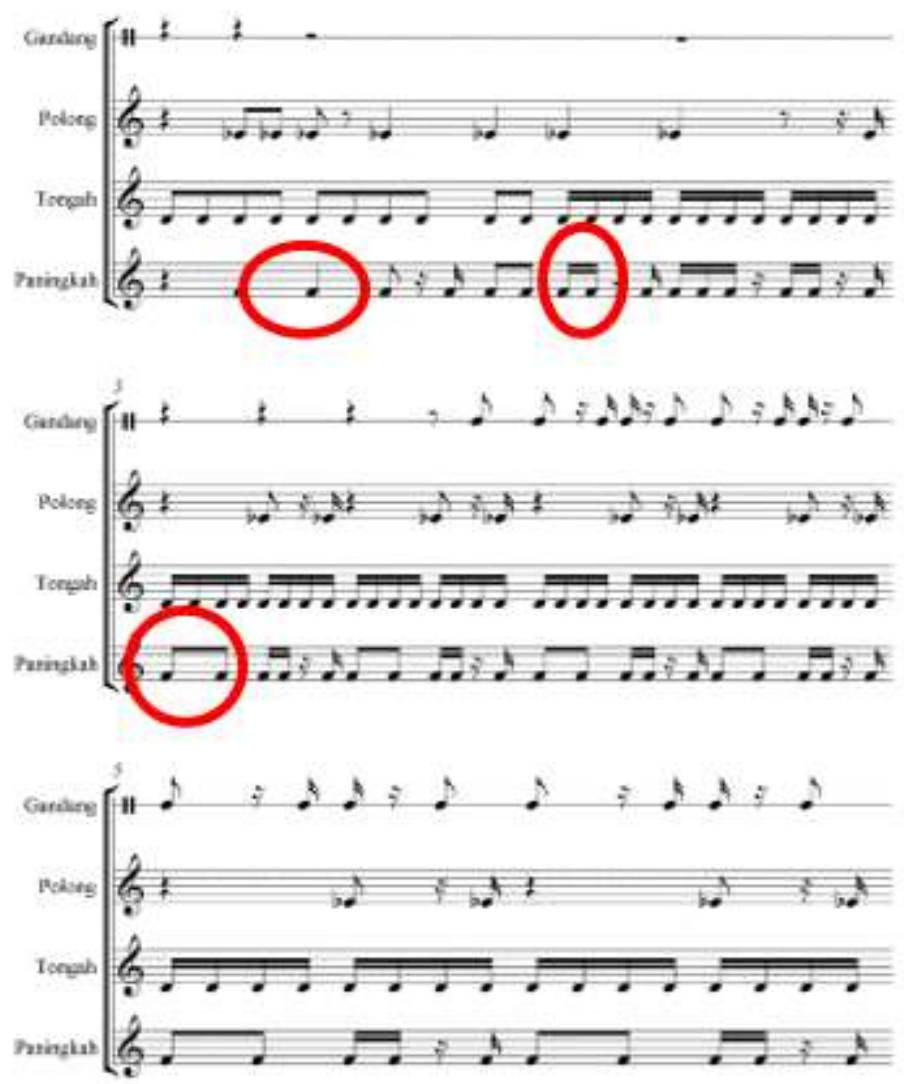

Gmabar 12. Varian Ritme dalam Struktur Lagu

Selain itu, kehadiran nada-nada Paningkah /garitiak secara kontinu selalu seiring dengan perjalanan melodi. Pengaturan nada-nada Paningkah sesekali jatuh pada bagian down-beat dan sesekali jatuh pada bagian up-beat.
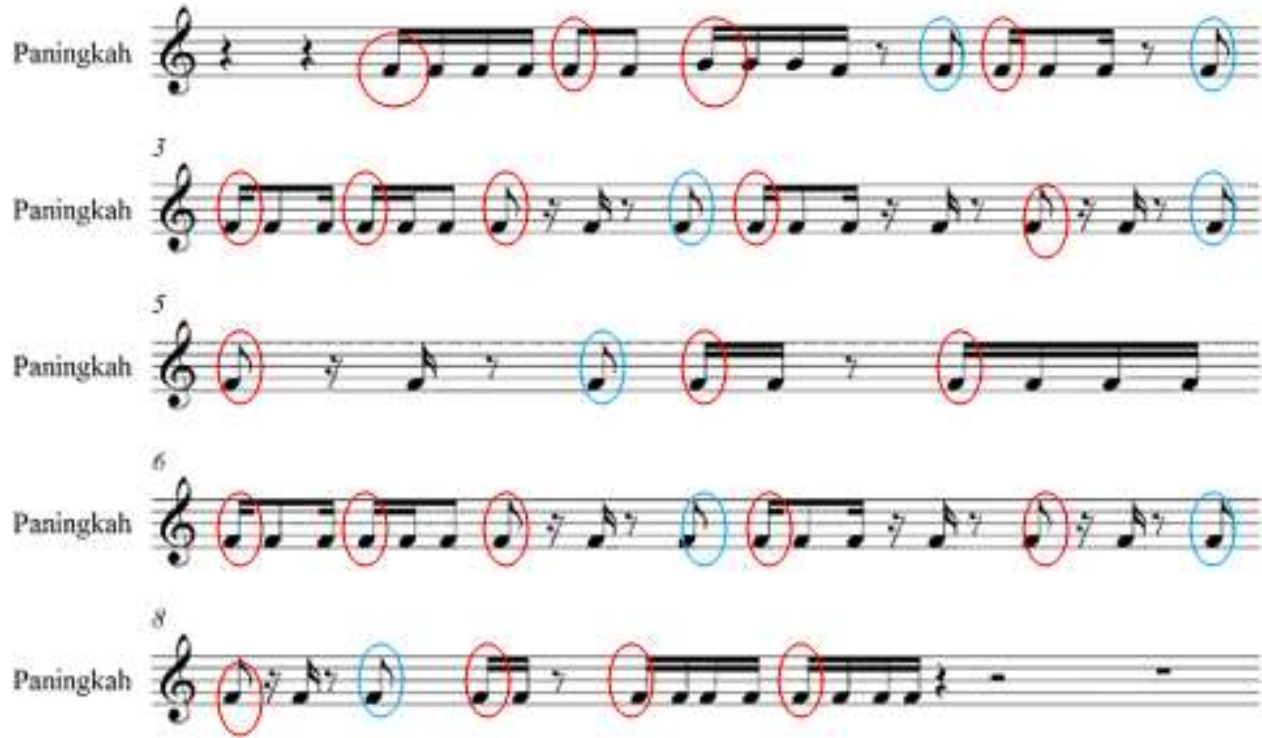

Gambar 13. Ritme down-beat dan up-beat. 
Dalam transkripsi ritme dari alat Talempong Paningkah dapat dilihat bahwa terdapat beberapa ritme yang jatuh pada ketukan up-beat dan down-beat. Untuk keperluan penulisan notasi dapat disimbolkan bahwa lingkaran yang berwarna merah merupakan penandaan terhadap ritme yang jatuh pada ketukan down-beat dan lingkaran yang berwarna biru merupakan penandaan terhadap ritme yang jatuh pada ketukan up-beat.

\section{SIMPULAN}

Talempong merupakan salah satu alat musik tradisional Minangkabau yang masih eksis sampai sekarang di tengah-tengah masyarakat pendukungnya. Apa bila di klasifikasikan ke dalam pengelompokan alat musik, Talempong termasuk ke dalam alat musik idiophone yang sumber bunyinya berasal dari badan alat musik itu sendiri. Ada dua jenis kesenian yang menggunakan alat musik Talempong sebagai inti dari pertunjukan tersebut, yang pertama kesenian Talempong Pacik dan kesenian Talempong Duduak (melodi).

Kesenian Talempong Pacik merupakan jenis kesenian pertama yang menggunakan instrument Talempong sebagai inti dari pertunjukan tersebut. Permainan Talempong pada kesenian Talempong Pacik pada umunya menggunakan tekhnik interlocking (saling mengisi) yang biasanya dimainkan dengan 3 orang pemain Talempong yang masing-masingnya memainkan 2 buah Talempong. Setiap daerah di Minangkabau memiliki ciri khas Talempong Pacik yang menjadi identitas bagi masyarakat di daerah tersebut salah satu nya yaitu kesenian Talempong Pacik Ikua Parik yang terdapat di jorong Ikua Parik, nagari Limbanang, Kecamatan Suliki , Kabupaten Lima Puluh Kota. Pada kesenian Talempong Pacik Ikua Parik tekhnik memainkan Talempong sangat berbeda dengan tekhnik memainkan Talempong Pacik pada umumnya (interlocking). Pada sistem interlocking, permainan talempong cenderung bersifat ritmis karena tidak adanya melodi pokok yang dibentuk dari permainan tersebut, akan tetapi pada kesenian Talempong Pacik Ikua Parik setiap talempong harus membentuk melodi dengan menggunakan tekhnik hoecketing (bersilang) .

Secara sekilas tekhnik hoecketing hampir sama dengan tekhnik interlocking, akan tetapi dalam tekhnik hoecketing, masing-masing Talempong cenderung membentuk suatu struktur melodi dengan perpaduan nada-nada yang di timbulkan dari masing-masing Talempong. Dalam satu pertunjukan Talempong Pacik Ikua Parik hampir sama dengan strukutur pertunjukan Talempong Pacik di Minangkabau umumnya. Adapun pemain Talempong di kesenian Talempong Pacik Ikua Parik disebut Polong, Tongah, Paningkah.

Lagu yang sering dibawakan pada suatu struktur kesenian Talempong Pacik Ikua Parik yaitu lagu-lagu dendang Saluang Darek yang salah satunya yaitu lagu Mudia Arau. Secara filosofi, kesenian Talempong Pacik Ikua Parik sebenarnya di pengaruhi oleh karakter alam nagari Limbanang. Nagari Limbanng merupakan daerah yang di aliri oleh banyak anak sungai dari Batang Sinamar. Hal ini juga terlihat dari karakter ritme yang dihasilkan oleh masing-masing Talempong di kesenian Talempong Pacik Ikua Parik cenderung mengalir walupun terdiri dari beberapa alat musik, akan tetapi melodi yang dibentuk akan terkesan mengalir. Hal ini juga dapat digambarkan dengan perumpamaan panuahnyo ndak sampai malimpah kariangyo ndak sampai babucak (penuhnya tidak sampai melimpah, keringnya tidak sampai ke dasar) , tercermin pula dalam konsep ornamentasi (garitiak) Talempong tingkah. Artinya kestabialan ritme garitiak harus dalam porsi yang sewajarnya. Jika Ritme garitiak berlebihan maka akan menutupi (membanjiri) bangunan melodi lagu sehingga melodi tidak terdengar jelas, sebaliknya apabila terlau jarang, akan membuat melodi utama akan terkesan kering. 
Grenek: Jurnal Seni Musik Vol. 10 No. 1 (Juni 2021) Page: 46-59

Prodi Pendidikan Musik FBS Unimed

p- ISSN 2301-5349

e- ISSN 2579-8200

\section{Daftar Pustaka}

Budhidharma, P. (2001). Seri Pustaka Musik Farabi, Buku Kerja Teori Musik : Sebagai Pengantar Komposisi dan Aransemen. Jakarta: PT Elex Media Komputindo Gramedia.

Fulzy, N. (2011). Estetika Musik Talempong Lagu Dendang di Nagari Limbanang. Ekspresi Seni, 13(2), 184-190.

Kuswara, A. B., Yensharti, \& Toruan, J. L. (2013). Studi Deskriptif Non Harmonic Tones Pada Lagu Anak-anak Karya A.T. Mahmud. Jurnal Sendratasik, 2(1).

Moleong, L. (2005). Metodologi Penelitian Kualitatif. Bandung: PT. Rosdakarya.

Muttaqin, M. (2008). Seni Musik Klasik. Jakarta: Direktorat Pembinaan Sekolah Menengah Kejuran, Departemen Pendidikan Nasional.

Purnomo, T. W. (2017). Studi Deskriptif Teks dan Konteks Musik Tradisional Irish Uilleann Pipes pada Lagu The Gender in The Pratie Hole. Gondang: Jurnal Seni dan Budaya, 1(2), 4962.

Sukerta, P. M. (2011). Metode Penyusunan Karya Musik (Sebuah Alternatif). Surakarta: ISI Press Solo. 